\title{
Latvian Scientist Jānis Stradiṇš Turns 80
}

\author{
Alīda Zigmunde \\ Institute of Humanities, \\ Riga Technical University \\ 16/20 Azenes Street, Room 431 \\ Riga LV-1048, Latvia \\ E-mail: alida.zigmunde@rtu.lv; azigmunde@web.de
}

Jānis Stradiņ̌̌ will celebrate his $80^{\text {th }}$ birthday on 10 December 2013. Having authored several hundred scientific articles and 28 books about a wide variety of subjects, he is the best known and one of the most productive scientists in Latvia. Stradinšs studied chemistry and was quite successful in his profession, but his activities were not limited to chemistry. His father, the well-known Latvian surgeon, Pauls Stradinš (1896-1958) was very interested in history of medicine and since 1953 was the director of the association of historians of medicine. In the early 1930s he started a private collection on history of medicine and the collection became the basis of the Pauls Stradinš Museum for the History of Medicine, founded in 1957.

The future academician Jānis Stradiņš, who used to watch his father at work, listened to his father's many discussions with his guests and read the books in his father's library, helped him in these activities. So ever since his youth, Jānis Stradiñš was interested in history of science and over the years he became interested in the history of chemistry, pharmacy, medicine, physics; the universities and research centers of the Baltic countries; biographies of eminent scientists; the intellectual history of Riga and Latvia through eight centuries, and the international scientific and cultural relations in Europe: West-East, NorthSouth, Latvia and Latvians in the world, and intellectual cooperation in the Baltic region. Stradinš never stopped enlarging the scope of his activities. By now, he has been active in the field of history of science for more than half a century, studying the research process and science as such.

When Pauls Stradinš organized a conference in Riga in June 1958 about research problems in the history of natural sciences and medicine with participants from Estonia, Latvia and Lithuania, and guests from Moscow and Leningrad, Jānis Stradinš̌ participated in this effort and together with his father prepared a 


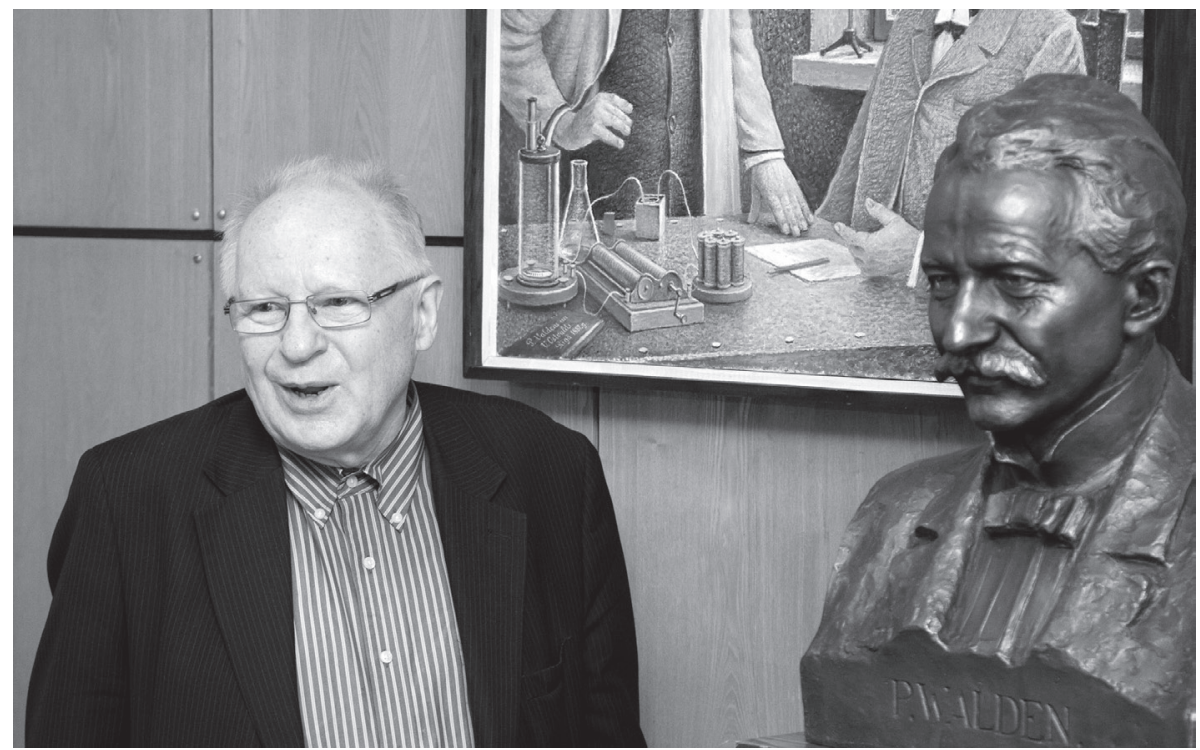

Jānis Stradinš̌ on May 14, 2013 at the occasion of issuing a Latvian postage stamp to commemorate the $150^{\text {th }}$ anniversary of Paul Walden. Stradiňš is standing next to the bronze bust of Paul Walden by K. Rončevskis. On the wall there is a painting Paul Walden and Wilhelm Ostwald, Riga 1887 by A. Bauškenieks. Photo by E. Lapsa.

lecture about the common issues in the history of science in the Baltic region. This initiated the tradition of joint Baltic conferences on the history of science, successively held in Riga, Vilnius/Kaunas, and Tartu/Tallinn.

In the meantime (1958-2012) twenty-five conferences have been held, the most recent of which was held in Vilnius in 2012. Nine conferences have taken place in Latvia, eight in Estonia and eight in Lithuania. It has not been easy to organize these conferences as they had to be coordinated horizontally across the three Baltic republics and vertically with the involvement of the leading colleagues in Moscow. The Baltic conferences have been well attended by prominent historians of science from Russia (Moscow and St. Petersburg, then Leningrad), the Ukraine, Belarus, Georgia, and elsewhere), and attracted also colleagues from Bulgaria, Poland, the German Democratic Republic, and Finland.

Organizing the conferences has been anything but easy—because of the nature of the period it was necessary to write and speak in a way that it would not be understood as being wrong or unwanted. In case of any suspicion of political or ideological wrongdoing, all the research and conferences were under threat of 
being banned. So politics and other suspicious subjects were carefully avoided. History of science and of medicine was a safer area of study as much of it dealt with the former Russian Empire and, of course, the research did not cover the former independent states of Estonia, Latvia and Lithuania. The results of the studies were published in a collection of articles in Russian language $I z$ istorii estestvoznaniia $i$ tekhniki Pribaltiki ('On the history of natural sciences and technology in the Baltics', 10 volumes, 1968-1992) and in Iz istorii meditsiny ('On the history of medicine', 19 volumes, 1957-1991). The Baltic scholars studied historical evidences of the development of the natural sciences and technology in the Baltic countries.

When Gorbachev's perestroika started, the Baltic historians of science were finally given an opportunity to be independent in establishing and maintaining direct contacts with foreign colleagues and organizations.

Discussion emerged about establishing the Baltic Coordinating Commission on the History of Science and Medicine and, in addition, an independent association, because the Baltic countries had already declared their independence by that time. In 1990, the establishing assembly in Riga brought together 33 historians of natural sciences, technology and medical sciences from Latvia, Lithuania and Estonia. As a result, the Baltic Association of the History and Philosophy of Science (BAHPS) was founded, and academician Jānis Stradiņ̌̌ undoubtedly deserves merit for that.

Even more so, the functioning of BAHPS would have been unthinkable without Jānis Stradiņš, the member of the academy. He took part in all of its 25 conferences with a lecture and was absent only twice due to important reasons-once due to health (the $17^{\text {th }}$ conference in Tartu) and once because he was on an official visit to Italy (the $22^{\text {nd }}$ conference in 2006 in Vilnius/Kaunas). Nevertheless, in both cases he had prepared a lecture which was read by a colleague.

Among his monumental literary and scientific works is the comprehensive monograph The Beginnings of Science and Higher Education in Latvia (in Latvian with summaries in English and Russian, 2009), which covers the early period of the development of science and institutions of higher education in Latvia until the end of the $19^{\text {th }}$ century. In 2010, the book was awarded the Baltic Assembly Prize for Science, which is evidence of the need to write generalizing monographs. 
When the Estonian Association of the History and Philosophy of Science in close cooperation with Latvian and Lithuanian Associations of the History and Philosophy of Science decided to start publishing a new academic journal Acta Baltica Historiae et Philosophiae Scientiarum, Stradinš was invited to join the editorial board. Indeed, he is the embodiment of history of science in the Baltics and represents sciences in Latvia as such. Because of his research and publications on the history of science, Jānis Stradiņš has become highly popular and is invited to attend the jubilee celebrations of various institutions. Many assemblies of the intelligentsia in Latvia are unthinkable without his presence.

He excels in his kind modesty, cordiality and collegiality towards people whom he knows and does not know. Whoever has encountered him once will go around with positive emotions for a while. A young scientist who addresses him with a question receives an answer so loaded with information and comments concerning the resarch that he feels compelled to delve further into the matter. Jānis Stradiņ̌̌ encourages young scientists and thinks about who would be able to contribute to solving one question or another or who could participate in research. Owing to his encouragement, he has discovered scientists of different orientations. He has succeeded in ensuring that research for the (upcoming) Baltic Conferences on the History of Science will continue and that the work started by his father has not come to a standstill.

History of science in the Baltic region has evolved to a high level. Many of the topics have been initiated by Stradiñš, who has given much thought to the future development of this intellectual enterprise. One problem was the common language of the conferences, which at first was Russian. After the Baltic states became independent, Russian was no longer imperative. Scientists of the older generation would know German, which together with Russian is good for archival research. Nowadays, however, English has become lingua franca for international communication in research, so it seems to have been decided without having a need to make a decision.

Over the years, Stradinš has participated in several international congresses on history of science in Tokyo, Kyoto, Bucharest, Moscow, and Edinburgh (19711984).

Jānis Stradiņš is a man who keeps up with the times and has found that presently science is not funded as it should be. He has spoken about it and warned of the consequences and the risk that scientists who could contribute to the Latvian society would go abroad and be lost to their nation. 
It is remarkable how Stradinš has valued the contribution of Baltic Germans who from the foundation of Riga in 1201 until the Russian Revolution set the tone in culture, teaching and learning, and who founded the first universities and institutions of higher education in engineering and natural sciences. He acknowledged the facts which was not always an easy thing to do. When the Baltic states regained their independence in 1990, some scientists lost their reputation because they had stood too close to the former power. Jānis Stradiņš did not. There was nothing he would have to be ashamed of. His independence of making judgments about facts helped him avoid certain troubles after the downfall of Soviet power in Latvia. The third "national awakening", or the period of the Singing Revolution at the end of the 1980s is firmly associated with the name of Jānis Stradinšs. He was with the people of Latvia and embodied the intellectual thinking of the people of Latvia. Independent Latvia acknowledged his outstanding services and he was elected the president of the Latvian Academy of Sciences (1998-2004).

When studying Jānis Stradiņšs bibliography, a name that stands out is that of the Riga-born chemist Wilhelm Ostwald (1853-1932), the only Nobel Prize winner from the Baltics, a chemist of wide range, and an inspiration to young scientists. Jānis Stradinš has researched and written about Wilhelm Ostwald, so it is thanks to him that we know Ostwald quite well. Ostwald taught at the Riga Polytechnic School and at the University of Dorpat/Tartu and his $160^{\text {th }}$ anniversary will be celebrated in 2013. Thanks to Jānis Stradinšs, several monuments have been dedicated not only to Wilhelm Ostwald but also to other scientists and notable figures. A monument dedicated to Ostwald was erected in 2001. In 2003, a monument was built to remember the chemist Paul Walden (1863-1957), one of his important students at the Riga Polytechnic School. Many articles have been written about these outstanding scientists and other figures (Theodor von Grotthuss, Friedrich Zander, and others) in the Soviet times. However, writing about German scientists was restricted.

Stradiņš is full member of the German National Academy of Sciences Leopoldina (class of History of Science and Medicine, since 1994); full member (since 1991) and honorary senator (since 2011) of the European Academy of Sciences and Art (in Salzburg, since 1991); corresponding member of Baltische Historische Kommission (University of Göttingen, since 1991) and member of many other organizations (for further information see www.lza.lv/scientists/stradinsj.htm).

Stradinš has written so many articles, and received so many awards that it is impossible to list them all in this article, so it is a good idea to discuss what Jānis 
Stradiņš is doing in the year of his $80^{\text {th }}$ jubilee. Stradinš is a highly sought-after lecturer and speaker at different events not only in Riga but also elsewhere in Latvia, which is taking quite much of his time. The year 2013 marks the $150^{\text {th }}$ anniversary of Paul Walden, the famous Latvian chemist mentioned above. In 2013, owing to the efforts of Jānis Stradinšš, Paul Walden was honored by having a street on the territory of the Riga Technical University named after him. A street with his name exists also in Valmiera/Wolmar and there are also some sites in his remembrance in the outskirts of this Livonian town. An interesting fact is that Paul Walden spent the second half of his life studying history of science and history of chemistry. So Jānis Stradiņš is continuing what Paul Walden once started.

Apart from his daily responsibilities, Stradiņš is working intensively on a book Latvia and the Latvians. The book will be published in four volumes in Latvian and English. The academician Jānis Stradinš is the editor and one of the many authors of the book. There was never a lack of plans for the future and he is active every day to pursue his goals. We wish him good health and success in so useful an occupation! 